\section{Contribution of a Winter Wheat Cover Crop to the Maintenance of Root Lesion Nematode Populations in the Red Raspberry Production System}

\author{
Rachel E. Rudolph ${ }^{1,5}$, Thomas W. Walters ${ }^{2}$, Lisa W. DeVetter ${ }^{3}$, \\ and Inga A. Zasada ${ }^{4,6}$
}

AdDITIONAl INDEX wORDs. Pratylenchus penetrans, Rubus idaeus, Triticum aestivum, cultural practices, nematicides

Summary. One of the primary production challenges red raspberry ( $R u b u s$ idaeus) growers in the Pacific northwestern United States confront is root lesion nematode [RLN (Pratylenchus penetrans)]. In this perennial production system, red raspberry serves as a sustained host for RLN. When a red raspberry planting is slated for removal in the fall, a new red raspberry planting quickly follows in the same field the following spring. The primary crop that occurs in rotation with red raspberry is a winter wheat cover crop to provide soil coverage and protection during the winter. The objectives of this research were to determine if winter wheat (Triticum aestivum) provides a green bridge for RLN in continuous red raspberry production systems and to determine if modified winter cover cropping practices can be used to reduce population densities of RLN before replanting red raspberry. Four trials were established in fields being replanted to red raspberry and the following modified winter cover cropping practices were considered: cover crop planting date (at fumigation or 2 weeks after fumigation), termination date (cover crop kill with herbicide 2 or 6 weeks before incorporation compared with the industry standard of incorporation immediately before planting), and the additional application of methomyl. 'Rosalyn' and 'Bobtail' winter wheat planted as cover crops in these trials were demonstrated to be maintenance hosts for RLN (ranging from 10 to 947 $\mathrm{RLN} / \mathrm{g}$ winter wheat root across trials) allowing them to be a green bridge for RLN to infect the following red raspberry crop. Altering winter wheat cover crop planting date, termination date with herbicide, or methomyl application did not affect RLN population densities in the subsequent red raspberry crop. Although planting an RLN maintenance host may be of concern to growers, the advantages of reduced soil erosion and nitrate leaching associated with cover cropping outweigh the perceived risk to the subsequent red raspberry crop.

A n important component for the sustainable production of red raspberry in the Pacific northwestern United States [PNW (includes Washington and Oregon)] is the use of winter cover crops before establishing the next planting. Because of the limited land suitable for red raspberry production, PNW growers commonly replant in the same location after removing the previous planting. After the last summer harvest, all trellising infrastructure is removed, canes are mowed, and the plant material is chopped and incorporated into the soil. Soil fumigation commonly occurs in the summer or early fall shortly after the incorporation of the plant material when soil temperatures are still above $50{ }^{\circ} \mathrm{F}$. Heavy and frequent precipitation is common during winter in the PNW. A winter cover crop is often overseeded before fumigation to provide soil coverage and protection during this time. In the early spring, beds are shaped and bare-root or tissue culture red raspberry is planted. Trellising infrastructure, including posts and wire, is then put in place.

One of the primary production challenges red raspberry growers confront is soilborne diseases, which includes root lesion nematodes (Zasada et al., 2015). This migratory endoparasite moves between soil and plant roots and has a broad host range of more than 400 plant species (Castillo and Vovlas, 2007). A common strategy to manage RLN in red raspberry is through preplant soil fumigation, primarily with fumigants containing 1,3-dichloropropene (1,3-D), chloropicrin, or methyl isothiocyanates (e.g., metam sodium) (Walters et al., 2017). Depending on the grower's needs, soil fumigation can occur in the late summer/early fall or spring before planting. The efficacy of this application depends on land preparation, soil type, and temperature. In the red raspberry production system, fumigants are applied without covering the soil with a polyethylene or impermeable tarp, which can leave the top 4-6 inches of soil untreated, making it a reservoir for RLN in sandy soils (Kroese et al., 2016). Application of post-plant nematicides is an additional option for red raspberry growers attempting to manage RLN. However, only oxamyl (Vydate $^{\circledR}$ L; DuPont Agricultural Products, Wilmington, DE) is presently being used, with application restricted to nonbearing acreage (Zasada and Walters, 2016).

Crop rotation has been suggested as a cultural management practice to reduce the severity of RLN and other soilborne diseases in the red raspberry system. Although crop rotation has many agronomic benefits, its efficacy for reducing RLN population densities is limited given the broad host range of this nematode. Furthermore, land suitable for red raspberry production is limited in the PNW and the justification to rotate to another crop species is often not economically viable. Red raspberry is a high-value crop and there are few crop alternatives of equal value

\begin{tabular}{llll}
\hline $\begin{array}{l}\text { Units } \\
\begin{array}{l}\text { To convert U.S. to SI, } \\
\text { multiply by }\end{array}\end{array}$ & U.S. unit & SI unit & $\begin{array}{l}\text { To convert SI to U.S., } \\
\text { multiply by }\end{array}$ \\
\hline 0.3048 & $\mathrm{ft}$ & $\mathrm{m}$ & 3.2808 \\
3.7854 & $\mathrm{gal}$ & $\mathrm{L}$ & 0.2642 \\
2.54 & inch(es) & $\mathrm{cm}$ & 0.3937 \\
1.1209 & $\mathrm{lb} / \mathrm{acre}$ & $\mathrm{kg} \cdot \mathrm{ha}^{-1}$ & 0.8922 \\
28.3495 & $\mathrm{oz}$ & $\mathrm{g}$ & 0.0353 \\
1 & $\mathrm{ppm}$ & $\mathrm{mg} \cdot \mathrm{L}^{-1}$ & 1 \\
6.8948 & $\mathrm{psi}$ & $\mathrm{kPa}$ & 0.1450 \\
1.1692 & $\mathrm{pt} / \mathrm{acre}$ & $\mathrm{L} \cdot \mathrm{ha}^{-1}$ & 0.8553 \\
2.3385 & $\mathrm{qt} / \mathrm{acre}$ & $\mathrm{L} \cdot \mathrm{ha}^{-1}$ & 0.4276 \\
$\left({ }^{\circ} \mathrm{F}-32\right) \div 1.8$ & $\mathrm{o} F$ & ${ }^{\circ} \mathrm{C}$ & $\left({ }^{\circ} \mathrm{C} \times 1.8\right)+32$
\end{tabular}


to which PNW growers can rotate. For this reason, PNW growers practice a very limited, short rotation with a winter cover crop (Pacific Northwest Extension, 2007). The winter cover crop most commonly used by red raspberry growers is winter wheat, which is grown in between late summer/ early fall fumigation and spring planting the following year. A winter wheat cover crop is normally seeded before fumigation because seeds are able to survive exposure to fumigants at the shallow depth of seeding. Although this cover crop helps maintain soil health and limits erosion during the winter months, it may also be an unintentional green bridge for RLN into the next red raspberry crop.

Because winter wheat may serve as a green bridge for RLN to infect the following crop, managing RLN populations while maintaining a cover crop is a potentially effective compromise. Therefore, applying a nematicidal product to the cover crop may be a viable option. Although oxamyl is used as a post-plant nematicide in nonbearing raspberry (Zasada and Walters, 2016), it is not labeled for use on wheat. Methomyl (Lannate ${ }^{\circledR}$ LV, DuPont Agricultural Products) is a broad-spectrum insecticide that has also been shown to be effective against root-knot nematodes [Meloidogyne incognita (Desaeger et al., 2011)] and is registered for use in wheat. However, it has not yet been evaluated against RLN.

We thank the Washington State Department of Agriculture Specialty Crop Block Grant Program and Washington Red Raspberry Commission for funding this research. We also thank the grower cooperators as well as Megan Kitner and Sean Watkinson for technical support.

The mention of trade names or commercial products is solely for the purpose of providing specific information and does not imply recommendation or endorsement by the U.S. Department of Agriculture.

${ }^{1}$ Department of Horticulture, University of Kentucky, N-322C Agriculture Science North, Lexington, KY 40506

${ }^{2}$ Walters Agriculture Research, 2117 Meadows Lane, Anacortes, WA 98221

${ }^{3}$ Department of Horticulture, Northwestern Washington Research and Extension Center, Washington State University, 16650 SR 536, Mount Vernon, WA 98273

${ }^{4}$ U.S. Department of Agriculture-Agricultural Research Service Horticultural Crops Research Unit, 3420 NW Orchard Avenue, Corvallis, OR 97330

${ }^{5}$ Former Washington State University Graduate Student.

${ }^{6}$ Corresponding author. E-mail: inga.zasada@ars. usda.gov.

https://doi.org/10.21273/HORTTECH03971-18
The objectives of this project were 2 -fold: 1 ) to determine if winter wheat provides a green bridge for RLN in continuous red raspberry production systems, and 2) to determine if modified winter cover cropping practices can be used to reduce population densities of RLN before replanting red raspberry. Cover cropping practices under investigation included modification of planting and destruction times, as well as methods of destruction (tillage or herbicide), which included the additional application of a systemic insecticide with nematicidal properties.

\section{Materials and methods}

All experimental trials were established in commercial red raspberry fields in Lynden, WA. The sites had a history of RLN, verified through presampling soils by the investigators. In all trials, the same sequence of events occurred to establish the experiments. In the late summer/early fall of the year in which the trial was established, the existing red raspberry planting was ended by chopping the canes. The canes, old roots, and crowns were incorporated into the soil, and the soil was prepared for fumigation. The entire experimental areas were broadcast fumigated by the grower cooperator or custom fumigator in September or October, as per standard industry practices for red raspberry production in the PNW. Immediately before fumigation, a winter wheat cover crop was broadcast seeded followed by a roller across the entire experimental area upon which treatments were established (see the following paragraphs for specific methods in each trial). In the late winter/early spring following fumigation, the cover crops were destroyed and/or incorporated, raised beds were created (except Trial 4 , which was not planted on raised beds), and a red raspberry cultivar of the growers' choice was planted. Trial sites were then maintained by the growers for the duration of the experiments following industry standard practices (Pacific Northwest Extension, 2007). The specifics of each trial are described in the following paragraphs.

Trials 1 and 2 were established in two growers' fields in 2014. The soil types in Trial 1 and 2 are a Lynnwood sandy loam and a Lynden sandy loam, respectively. The following treatments were evaluated in both trials: l) a winter wheat cover crop not killed before incorporation (No Kill); 2 ) a winter wheat cover crop killed 6 weeks before incorporation (Early Kill); 3) a wheat cover crop killed 2 weeks before incorporation (Late Kill); and 4) a winter wheat cover crop killed 2 weeks before incorporation plus the application of methomyl (Late Kill + methomyl). All treatments were replicated four times in each field and arranged in a randomized complete block design. Each experimental unit (plot) was $30 \mathrm{ft}$ wide and $50 \mathrm{ft}$ long. 'Bobtail' winter wheat was seeded in both fields at a rate of $100 \mathrm{lb} /$ acre immediately before fumigation with $65 \% 1,3-\mathrm{D}$ and $35 \%$ chloropicrin (Telone ${ }^{\circledR}$ C-35; Dow AgroSciences, Indianapolis, IN). To achieve cover crop kill at either 2 or 6 weeks before incorporation, glyphosate (Cornerstone ${ }^{\circledR}$ Plus; Winfield Solutions, Shoreview, MN) at $2 \mathrm{qt} /$ acre plus $2.5 \%$ adjuvant (Class Act $^{\mathbb{B}}$; WinField Solutions) was applied with a handheld sprayer (Chapin ${ }^{\circledR}$ International, Batavia, NY). Methomyl was applied at $3 \mathrm{pt} /$ acre using a carbon dioxide $\left(\mathrm{CO}_{2}\right)$-powered backpack sprayer at 30 psi using a four-nozzle boom and 8002 nozzles (Teejet ${ }^{\circledR}$ Technologies, Glendale Heights, IL) in a volume of $3.1 \mathrm{~L} /$ plot. Early kill of the winter wheat cover crop in both trials occurred on 7 Jan. 2015 and late kill occurred on 16 Feb. 2015. In both trials, the experimental area was cultivated and 36-inch-wide raised beds were formed using the growers' bed shaper. Root cuttings of 'Meeker' red raspberry were planted in Trial 1 on 1 Mar. 2015, whereas tissue cultured 'Wakefield' red raspberry plants were planted in Trial 2 on the same day.

In 2015 , two more trials were established (Trials 3 and 4 ) in different field sites. In Trial 3, the following treatments were evaluated: 1) a winter wheat cover crop not killed before incorporation (No Kill); 2) a winter wheat cover crop killed 6 weeks before incorporation (Early Kill); $3)$ a winter wheat cover crop killed 6 weeks before incorporation plus the application of methomyl (Early Kill + methomyl); 4) a winter wheat cover crop killed 2 weeks before incorporation (Late Kill); and 5) a winter wheat 
cover crop killed 2 weeks before incorporation plus the application of methomyl (Late Kill + methomyl). Early and late kill occurred on 8 Jan. and 13 Feb. 2016, respectively. The soil type at this site is a Lynden sandy loam. The experimental design, plot size, rates of glyphosate and methomyl, and application method were the same to that described for the 2014 trials. Soil fumigation occurred right before late planting of 'Bobtail' winter wheat using 65\% $1,3-\mathrm{D}$ and $35 \%$ chloropicrin with a metam sodium cap (Vapam ${ }^{\circledR}$; AMVAC Chemical Corp., Newport Beach, CA). Root cuttings of 'Meeker' red raspberry were planted $\approx 17$ Feb. 2016 and maintained by the cooperating grower.

In addition to modifying the date of cover crop kill with herbicide and the application of methomyl, cover crop planting date was also modified in Trial 4 . This experimental design was a $2 \times 2 \times 2$ factorial with two cover crop planting dates, Early and Late (30 Sept. and 17 Oct. 2015), two glyphosate application dates, Early and Late ( 2 and 6 weeks before cover crop kill, 8 Jan. and 13 Feb. 2016), and two methomyl treatments ( \pm methomyl; applied 12 Jan. and 16 Feb. 2016). Treatments were replicated four times in plots $20 \mathrm{ft}$ wide and $50 \mathrm{ft}$ long. The soil type at this site is a Lynden sandy loam. For the early seeding, 'Rosalyn' winter wheat was seeded at a rate of 150 $\mathrm{lb} /$ acre immediately before fumigation. For the late seeding, the same winter wheat cultivar was seeded at a higher rate $(170 \mathrm{lb} /$ acre $)$ to accommodate for the later planting time and cooler soil temperatures. Glyphosate (Touchdown Total ${ }^{\circledR}$; Syngenta, Greensboro, NC) was applied at $2 \mathrm{qt} /$ acre with $2.5 \%$ adjuvant (Class Act ${ }^{\circledR} \mathrm{NG}^{\circledR}$; WinField Solutions) either alone or in combination with methomyl at $3 \mathrm{pt} / \mathrm{acre}$. A $0.25 \%$ silicone surfactant (Silkin ${ }^{\circledR}$; Winfield Solutions) was also included with the applications. All applications were performed with a $\mathrm{CO}_{2}$ backpack sprayer as previously mentioned. At the time of cover crop incorporation, the ground was mechanically cultivated and bare-root 'Meeker' red raspberry canes were planted on 18 Mar. 2016 and maintained by the cooperating grower. No raised beds were used in this trial.
In all trials, RLN population dynamics were monitored over time. Soil and root (when plants were present) samples were collected l) from red raspberry soil before the termination of the previous red raspberry crop and establishment of treatments, 2) from winter wheat roots and surrounding soil in January before the treatment application, 3) from soil immediately before red raspberry planting but after bed formation, when applicable, and 4) from red raspberry roots and soil the following fall $\approx 6$ months (all trials) and 1.5 years (Trials 1,2 , and 4 ) after red raspberry planting. Soil samples were the composite of $8-10$ cores $(1 \times$ 8 inches) collected within each plot. For the collection of winter wheat roots, $\approx 10$ winter wheat plants were collected from each plot. For the collection of red raspberry roots, two to three root cores, $6 \times 6 \times 6$ inches, were collected within 8 inches from the crown of the plant within the bed. Root lesion nematodes were extracted by placing a $50-\mathrm{g}$ soil sample on a Baermann funnel with nematodes collected after $5 \mathrm{~d}$ (Zasada et al., 2015). Extraction of RLN from roots was conducted by placing washed roots under intermittent mist, $15 \mathrm{~s}$ every $2 \mathrm{~min}$, with nematodes collected after $5 \mathrm{~d}$ (Zasada et al., 2015). Root lesion nematodes were identified and enumerated using a dissecting microscope at $\times 40$ magnification. Population densities of RLN are expressed as number per $100 \mathrm{~g}$ of soil or number per gram of dry root.

Soil and root nematode population density data were $\log (x+10)$ transformed when necessary to meet the assumptions of analysis of variance (ANOVA). ANOVA was used to determine significance of treatment effects on nematode population densities with treatments and treatment combinations as fixed effects and block as a random effect. When possible, repeated measures were used to analyze RLN population density data within each trial across sampling dates. Means separations were carried out using Tukey adjustment for multiple comparisons (SAS version 9.3; SAS Institute, Inc., Cary, NC). Alpha was set at 0.05 for all data. All data presented in tables are the original, nontransformed means and standard errors.

\section{Results}

Winter WHEAT AS A GREeN BRIDGE FOR RLN. The sites on which Trials 1, 3, and 4 were conducted are considered high-pressure RLN sites with population densities $>100$ $\mathrm{RLN} / 100$ g soil (range 283-621 RLN/100 g soil), whereas Trial 2 was considered a low-pressure RLN site with a population density of $29 \pm 12 \mathrm{RLN} / 100 \mathrm{~g}$ soil (McElroy, 1992). Across the four trials, RLNs were found at all sites both pre- and posttreatment application. At the low-pressure RLN site, the range of RLN recovered from winter wheat roots was 10-79 RLN/g dry root (Table 1), whereas at the highpressure RLN sites, population densities range from 17 to 947 $\mathrm{RLN} / \mathrm{g}$ dry root (Tables $1-3$ ). In general, across trials, there were very few RLN recovered from the soil surrounding winter wheat roots in the winter (Tables $1-3$ ).

MANAGEMENT OF RLN IN WINTER WHEAT COVER CROPS. Before applying treatments in all trials, there were no differences among treatment plots in population densities of RLN in roots or soil $[P>0.05$ (Tables $1-3)]$. In Trial 1 at planting, few RLN were found in soil in any of the treatments (Table 1). In the subsequent red raspberry crop, there were no significant differences in population densities of RLN in red raspberry roots or surrounding soil among treatments on Sept. 2015 [6 months after planting $(P=0.38$ and 0.55 , respectively)] or Oct. 2016 [ 1.5 years after planting $(P=0.60$ and 0.73 , respectively $)]$ (Table 1). Across treatments, RLN population densities in red raspberry roots were significantly greater in Oct. 2016 compared with those in Sept. $2015(P<0.05)$. Soil population densities of RLN were significantly greater in Oct. 2016 compared with Sept. 2015 in the Late Kill and Late Kill + methomyl treatments $(P=$ 0.022 and 0.032 , respectively), but not in the Early Kill or the No Kill treatments.

In Trial 2, there were no RLN found in soil samples at planting. Six months (Sept. 2015) after planting, there were no significant differences among treatments in RLN densities in either red raspberry roots or soil $[P=0.52$ and 0.51 , respectively (Table 1)]. In Oct. 2016, 
Table 1. Population densities of root lesion nematode (RLN) in winter wheat and red raspberry roots and surrounding soil over time in trials with four replications evaluating the impact of wheat termination timing with glyphosate and methomyl application to wheat on RLN management.

\begin{tabular}{|c|c|c|c|c|c|c|c|}
\hline \multicolumn{4}{|c|}{$\operatorname{RLN}[\text { mean } \pm \text { SE }(\text { no. } / g \text { dry root })]^{\mathrm{z}}$} & \multicolumn{4}{|c|}{$\operatorname{RLN}[\text { mean } \pm \text { SE }(\text { no. } / 100 \mathrm{~g} \text { soil })]^{\mathrm{z}}$} \\
\hline Treatment $^{\mathrm{y}}$ & $\begin{array}{c}\text { Jan. } 2015 \\
\text { (winter } \\
\text { wheat) }\end{array}$ & $\begin{array}{c}\text { Sept. } 2015 \\
\text { (red } \\
\text { raspberry) }\end{array}$ & $\begin{array}{l}\text { Oct. } 2016 \\
\text { (red } \\
\text { raspberry) }\end{array}$ & $\begin{array}{c}\text { Jan. } 2015 \\
\text { (winter } \\
\text { wheat) }\end{array}$ & $\begin{array}{l}\text { Feb. } 2015 \\
\text { (at planting) }\end{array}$ & $\begin{array}{c}\text { Sept. } 2015 \\
\text { (red raspberry) }\end{array}$ & $\begin{array}{l}\text { Oct. } 2016 \\
\text { (red } \\
\text { raspberry) }\end{array}$ \\
\hline \multicolumn{8}{|l|}{ Trial $1^{x}$} \\
\hline No Kill & $283 \pm 168$ & $115 \pm 51$ & $3,347 \pm 1,199$ & $2 \pm 2$ & 0 & $46 \pm 27$ & $116 \pm 77$ \\
\hline Early Kill & $438 \pm 231$ & $35 \pm 25$ & $1,641 \pm 653$ & 0 & 0 & $46 \pm 23$ & $188 \pm 89$ \\
\hline \multicolumn{8}{|l|}{ Trial $2^{\mathrm{w}}$} \\
\hline No Kill & $121 \pm 112$ & $79 \pm 73$ & $76 \pm 37$ & 0 & $6 \pm 6$ & $19 \pm 19$ & $73 \pm 61$ \\
\hline Early Kill & $16 \pm 9$ & $15 \pm 13$ & $562 \pm 510$ & 0 & $5 \pm 4$ & 0 & $116 \pm 64$ \\
\hline Late Kill & $86 \pm 37$ & $78 \pm 56$ & $131 \pm 28$ & 0 & $2 \pm 2$ & $12 \pm 8$ & $88 \pm 16$ \\
\hline Late Kill + methomyl & $10 \pm 6$ & $1 \pm 1$ & $401 \pm 284$ & 0 & 0 & 0 & $369 \pm 223$ \\
\hline
\end{tabular}

${ }^{\mathrm{z}} 1$ nematode $/ \mathrm{g}=28.3495$ nematodes $/ \mathrm{oz}, 1$ nematode $/ 100 \mathrm{~g}=0.2835$ nematode $/ \mathrm{oz}$.

${ }^{y}$ Treatment designations in both trials are as follows: No Kill $=$ termination by tillage right before red raspberry planting; Early Kill $=$ termination by glyphosate (herbicide) 6 weeks before red raspberry planting; Late Kill = termination by glyphosate (herbicide) 2 weeks before red raspberry planting; Late Kill + methomyl $=$ termination by glyphosate (herbicide) 2 weeks before red raspberry planting with the additional spray of methomyl.

${ }^{x}$ The soil was a Lynnwood sandy loam from a red raspberry field in Lynden, Washington. 'Meeker' red raspberry was planted at this site.

whe soil was a Lynden sandy loam from a raspberry field in Lynden, WA. 'Wakefield' raspberry was planted at this site.

Table 2. Population densities of root lesion nematode ( RLN) in winter wheat and red raspberry roots and surrounding soil over time in trials with four replications evaluating the impact of winter wheat termination timing with glyphosate and methomyl application on winter wheat on RLN management.

\begin{tabular}{|c|c|c|c|c|c|}
\hline \multicolumn{3}{|c|}{ RLNs $[$ mean \pm SE (no./g dry root $)]^{\mathrm{z}}$} & \multicolumn{3}{|c|}{ RLNs $[$ mean \pm SE (no./100 g soil $)]^{\mathrm{z}}$} \\
\hline Treatment $^{\mathrm{y}}$ & $\begin{array}{c}\text { Jan. } 2016 \\
\text { (winter wheat) }\end{array}$ & $\begin{array}{c}\text { Oct. } 2016 \\
\text { (red raspberry) }\end{array}$ & $\begin{array}{c}\text { Jan. } 2016 \\
\text { (winter wheat) }\end{array}$ & $\begin{array}{c}\text { Apr. } 2016 \\
\text { (at planting) }\end{array}$ & $\begin{array}{c}\text { Oct. } 2016 \\
\text { (red raspberry) }\end{array}$ \\
\hline \multicolumn{6}{|l|}{ Trial $3^{\mathrm{x}}$} \\
\hline No Kill & $114 \pm 80$ & $621 \pm 294$ & 0 & $3 \pm 3$ & $75 \pm 56$ \\
\hline Early Kill & $17 \pm 14$ & $314 \pm 133$ & $3 \pm 2$ & $2 \pm 2$ & $60 \pm 27$ \\
\hline Early Kill + methomyl & $24 \pm 10$ & $316 \pm 157$ & 0 & $3 \pm 2$ & $24 \pm 9$ \\
\hline
\end{tabular}

${ }^{\mathrm{z}} 1$ nematode $/ \mathrm{g}=28.3495$ nematodes $/ \mathrm{oz}, 1$ nematode $/ 100 \mathrm{~g}=0.2835$ nematode/oz.

${ }^{y}$ Treatment designations are as follows: No Kill = termination by tillage right before raspberry planting; Early Kill = termination by glyphosate (herbicide) 6 weeks before red raspberry planting; Early Kill + methomyl $=$ termination by glyphosate (herbicide) 6 weeks before red raspberry planting with the addition of methomyl; Late Kill $=$ termination by glyphosate (herbicide) 2 weeks before red raspberry planting; Late Kill + methomyl = termination by glyphosate (herbicide) 2 weeks before red raspberry planting with the addition of methomyl.

${ }^{\mathrm{x}}$ The soil was a Lynden sandy loam from a red raspberry field in Lynden, WA. 'Meeker' red raspberry was planted at this site.

1.5 years after planting, although numeric differences were observed in RLN population densities in roots and soil, these differences were not significant $[P=0.62$ and 0.31 , respectively (Table 1)].

In Trial 3 at planting, few RLN were found in soil and there were no differences among treatments at this time $(P=0.81)$. In the subsequent red raspberry planting, there were no significant differences among treatments in RLN densities in red raspberry roots or soil in Oct. $2016[P=$ 0.81 (Table 2)].

In Trial 4, when the main effect of planting date was considered before applying the other treatments, Early vs. Late, there was no significant difference $[P>0.05$ (data not presented)]. Early-planted winter wheat had an average of $404 \mathrm{RLN} / \mathrm{g}$ of root whereas late-planted winter wheat had an average of $736 \mathrm{RLN} / \mathrm{g}$ of root. At red raspberry planting, there was no significant interaction among the treatments for RLN population densities in soil $(P=0.10)$, nor were there significant differences in planting date $(P=0.80)$, termination date $(P=0.30)$, and insecticide application $(P=0.15)$ (Table 3$)$. Six months after planting (Oct. 2016), population densities of RLN in red raspberry roots were not different when evaluating the treatment interaction $(P=$ $0.47)$ or each treatment individually $(P>0.12)$ (Table 3$)$. Although the treatment interaction was not significant for RLN population densities in red raspberry soil, planting date was significant at this time $(P=0.01)$. Red raspberry planted in plots where winter wheat was planted after fumigation (Late) had significantly higher soil population densities of RLN compared with red raspberry planted before fumigation (Early). At the last sampling date, nearly 12 months later, there were no significant differences in RLN population densities in red raspberry roots $(P=0.34)$ or soil $(P=0.17)$ among the treatments.

\section{Discussion}

The results from this study demonstrate that the winter wheat 
Table 3. Population densities of root lesion nematode (RLN) in winter wheat and red raspberry roots and surrounding soil over time in a trial with four replications evaluating the impact of winter wheat planting and termination timing with glyphosate and with and without methomyl application on winter wheat on RLN management.

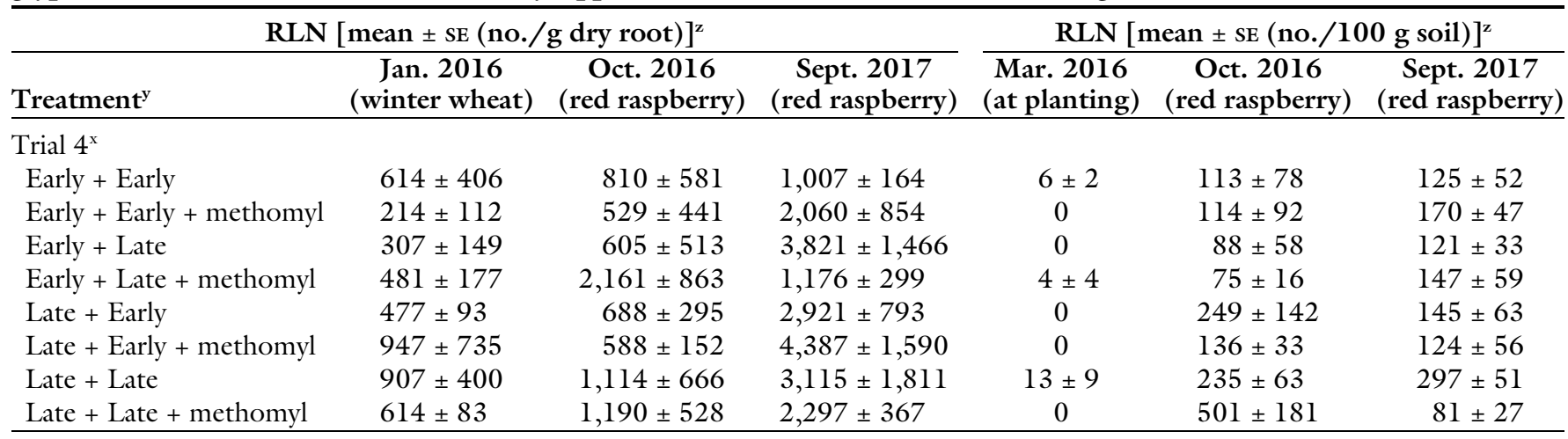

${ }^{\mathrm{z}} 1$ nematode $/ \mathrm{g}=28.3495$ nematodes $/ \mathrm{oz}, \mathrm{l}$ nematode $/ 100 \mathrm{~g}=0.2835$ nematode $/ \mathrm{oz}$.

yTreatment designations are as follows: Early + Early = September (early) winter wheat planting followed by early glyphosate (herbicide) termination of winter wheat 6 weeks before red raspberry planting; Early + Early + methomyl = September winter wheat planting followed by early glyphosate (herbicide) termination of winter wheat 6 weeks before red raspberry planting with methomyl application; Early + Late $=$ September winter wheat planting followed by glyphosate (herbicide) termination of winter wheat 2 weeks before red raspberry planting; Early + Late + methomyl = September winter wheat planting followed by glyphosate (herbicide) termination of winter wheat 2 weeks before red raspberry planting with methomyl application; Late + Early $=$ October (late) winter wheat planting followed by glyphosate (herbicide) termination of winter wheat 6 weeks before red raspberry planting; Late + Early + methomyl = October winter wheat planting followed by glyphosate (herbicide) termination of winter wheat 6 weeks before red raspberry planting with methomyl application; Late + Late $=$ October wheat planting followed by glyphosate (herbicide) termination of winter wheat 6 weeks before red raspberry planting; Late + Late + methomyl $=$ October winter wheat planting followed by glyphosate (herbicide) termination of winter wheat 6 weeks before red raspberry planting with methomyl application.

${ }^{x}$ The soil was a Lynden sandy loam from a red raspberry field in Lynden, WA. 'Meeker' red raspberry was planted at this site.

cultivars evaluated in these trials are suitable hosts for RLN over the winter in the floricane red raspberry production system, demonstrating that winter wheat provides a green bridge for RLN until red raspberry is planted in the spring. This research also demonstrates that attempting to manage RLN in a winter wheat cover crop by manipulating planting and termination date, as well as by applying methomyl did not appear to alter the outcome of nematode parasitism on the subsequent red raspberry crop.

The host suitability of winter wheat for RLN in PNW red raspberry has been previously evaluated (Rudolph et al., 2017). When planted in the alleyways between red raspberry beds without irrigation or fertilization, 'Rosalyn' winter wheat was a poor host for RLN. However, after conducting two greenhouse RLN host assays which included proper irrigation and fertilization, 'Rosalyn' winter wheat was shown to be a maintenance host for RLN with a reproductive factor $(\mathrm{RF}=$ final nematode population density/initial nematode population density) greater than 1.0 in both assays (Rudolph et al., 2017). When the RF is greater than 1.0, reproduction was successful on that particular plant host indicating that the plant is a host for the nematode. Although the host suitability of 'Bobtail' winter wheat for RLN has not been evaluated previously, 'Rosalyn' and 'Bobtail' are similar. Both are semidwarf soft, white winter wheat cultivars with one parent being 'Tubbs'. Both cultivars were developed by Oregon State University for the PNW region with rainfall $>16$ inches (Van Vleet et al., 2016). Based on our data, the host suitability of 'Bobtail' for RLN appears to be similar to that of 'Rosalyn' in that it is also a maintenance host. This may cause concern for growers who wish to avoid encouraging RLN populations in their fields. However, the soil quality benefits of winter cover crops most likely outweigh the RLN host concerns. In addition, many other winter-hardy cover crops have also been determined to be suitable hosts for RLN. Cultivars of cereal rye (Secale cereale), barley (Hordeum vulgare), oats (Avena sativa), clover (Trifolium repens), timothy grass (Phleum pratense), ryegrass (Lolium sp.), and sheep fescue (Festuca ovina) are all suitable RLN hosts (Forge et al., 2001; Rudolph et al., 2017; Thies et al., 1995; Vrain et al., 1996). Growers looking for an alternative winter cover crop to winter wheat may not find anything better than wheat. Maintaining bare soil during the winter in the PNW is also not a viable option; consistent rainfall during the winter months can lead to severe soil erosion and nitrate leaching.

Root lesion nematodes were able to colonize the root system of winter wheat after soil fumigation. In previous studies in PNW red raspberry, we observed that RLNs were missed at shallow depths in some soil types during nontarped soil fumigation (Kroese et al., 2016). In a course soil (70\% sand, $20 \%$ silt, and $10 \%$ clay), more RLNs survived at shallow soil depths $(0-30 \mathrm{~cm})$ compared with deeper soil depths $(31-90 \mathrm{~cm})$. This was different from what was observed in a finer soil (52\% sand, $32 \%$ silt, and $15 \%$ clay) where fewer RLNs were found at shallow compared with deeper soil depths. The soil types included in the present trials were all sandy loams, similar to the course soil type considered by Kroese et al. (2016), soils from which soil fumigants would be expected to more readily and rapidly move through shallow depths when left untarped (Qin et al., 2013). The lack of shallow efficacy of soil fumigation in this system is further demonstrated by the fact that wheat is seeded before fumigation and seeds survive fumigation to successfully germinate.

The alteration of planting date of the winter wheat cover crop was intended to evaluate whether RLN would persist in the soil if a root system was not immediately present 
for invasion post fumigation. It was hypothesized that if a host crop was not present for the nematode to invade, then some nematodes would starve before a host plant is present. In Trial 4, the only time that the main effect of planting date was significant was in red raspberry root samples in Oct. 2016; at this time, RLN population densities in red raspberry roots were higher in the Late ( 1 month after fumigation) vs. Early (at fumigation) planting date, disproving our hypothesis.

Termination date of the winter cover crop was also considered to evaluate whether the RLN population densities in the subsequent red raspberry crop would be smaller if there was not a host present immediately before planting red raspberry. Early termination of the cover crop did not significantly affect subsequent RLN population densities in red raspberry in any of the trials. However, there were trends for lower RLN population densities in Early and Late Kill treatments compared with the No Kill treatments in Trials 1 and 2. In Trial 2, the Late Kill + methomyl treatment had almost no RLN in roots and soil compared with the other treatments.

Our planting date and termination date data suggest that RLN can survive in soil during the periods of time between red raspberry removal and late cover crop establishment and early kill and spring red raspberry planting without a host. However, population densities of RLN were relatively low in the winter cover crops compared with that of red raspberry. This is most likely attributed to red raspberry being a better host for RLN than winter wheat or other grass cover crops. However, soil temperature could also play a factor. Root and soil for the cover crops were collected during the colder months of each year for each trial. Previous studies have observed that RLN densities decline when soil or media temperatures were low (Dickerson et al., 1964; Mizukubo and Adachi, 1997). The optimal soil temperature for RLN development is between 25 and $30{ }^{\circ} \mathrm{C}$ (Acosta and Malek, 1979; Kimpinski and Willis, 1981). However, RLN can still reproduce, albeit slower, at soil temperatures as low as $15{ }^{\circ} \mathrm{C}$ (Acosta and Malek, 1979).
The use of herbicides on the winter cover crop was evaluated to provide another way of ending the cover crop quickly to destroy the winter wheat crop and roots, thus decreasing RLN survival and persistence. The data suggest there was no added benefit to using herbicides to manage RLN in winter wheat. In addition, winter wheat would be ended by tillage in March before red raspberry planting, well before seed head formation and subsequent volunteer regrowth would be a concern. A study evaluating alleyway cover crops in red raspberry found that volunteer winter wheat did not occur after planting a winter wheat cover crop, and termination by tillage was effective (Rudolph et al., 2017). The use of herbicides is an unnecessary expense for growers to undertake.

Previous studies have demonstrated that methomyl suppresses plant-parasitic nematodes. In aqueous assays, rapid suppression of recently hatched root-knot nematode (M. incognita) second-stage juveniles (J2; $24 \mathrm{~h}$ old) was observed with methomyl at $4.9-15.2 \mathrm{mg} \cdot \mathrm{L}^{-1}$ (Desaeger et al., 2011). In greenhouse assays, methomyl drenched at rates of $0.56-4.0 \mathrm{~kg} \cdot \mathrm{ha}^{-1}$ also effectively suppressed root-knot nematode $\mathrm{J} 2$ on pea (Pisum satioum) and lima bean (Phaseolus lunatus) (Desaeger et al., 2011). In both of these studies, nematode suppression was similar to that of oxamyl. Methomyl also reduced hatch of the root-knot nematode (Meloidogyne hapla) at $2 \mathrm{ppm}$ (McLeod and Khair, 1975). When applied at 4-32 ppm, methomyl suppressed J2 development of the rootknot nematode (Meloidogyne javanica) in tomato (Solanum lycopersicum); at $32 \mathrm{ppm}$, nematode development was nearly zero (McLeod and Khair, 1975). Our data show that the use of methomyl to manage RLN would not be a reasonable expense for growers as there were no significant differences among treatments with or without methomyl. Methomyl can be applied as an overhead spray or as a soil drench. Root-knot nematode control was effective in assays performed in a controlled environment when methomyl was applied as a drench (Desaeger et al., 2011). In our study, methomyl was applied as an overhead spray to the winter wheat in fields, not in a controlled environment. The difference in application methods may account for the difference in efficacy.

The winter wheat cultivars planted as cover crops in these trials were demonstrated to be maintenance hosts for RLN allowing them to be a green bridge for the nematode to infect the following red raspberry crop. However, altering winter wheat planting date, termination date with herbicide, or methomyl application did not appear to affect the RLN population density in the subsequent red raspberry crop's roots or surrounding soil. Although planting a maintenance host may be of concern to growers, the subsequent red raspberry crop did not suffer significantly more.

\section{Literature cited}

Acosta, N. and R.B. Malek. 1979. Influence of temperature on population development of eight species of Pratylenchus on soybean. J. Nematol. 11:229232.

Castillo, P. and N. Vovlas. 2007. Pratylenchus (Nematoda: Pratylenchidae): Diagnosis, biology, pathogenicity and management. Koninklijke Brill, Leiden, The Netherlands.

Desaeger, J.A., M. Rivera, R. Leighty, and H. Portillo. 2011. Effect of methomyl and oxamyl soil applications on early control of nematodes and insects. Pest Mgt. Sci. 67:507-513.

Dickerson, O.J., H.M. Darling, and G.D. Griffin. 1964. Pathogenicity and population trends of Pratylenchus penetrans on potato and corn. Phytopathology 54:317-322.

Forge, T., A. Muehlchen, C. Hackenberg, G. Neilsen, and T. Vrain. 2001. Effects of preplant inoculation of apple (Malus domestica Borkh.) with arbuscular mycorrhizal fungi on population growth of the root-lesion nematode, Pratylenchus penetrans. Plant Soil 236:185-196.

Kimpinski, J. and C.B. Willis. 1981. Influence of soil temperature and $\mathrm{pH}$ on Pratylenchus penetrans and P. crenatus in alfalfa and timothy grass. J. Nematol. 13:333-338.

Kroese, D.R., J.E. Weiland, and I.A. Zasada. 2016. Distribution and longevity of Pratylenchus penetrans in the red raspberry production system. J. Nematol. 48:241-247.

McElroy, F.D. 1992. A plant health care program for brambles in the Pacific northwest. J. Nematol. 24:457-462. 


\section{Research Reports}

McLeod, R.W. and G.T. Khair. 1975. Effects of oximecarbamate, organophosphate and benzimidazole nematicides on life cycle stages of root-knot nematodes, Meloidogyne spp. Ann. Appl. Biol. 79: 329-341.

Mizukubo, T. and H. Adachi. 1997. Effect of temperature on Pratylenchus penetrans development. J. Nematol. 29:306-314.

Pacific Northwest Extension. 2007. Commercial red raspberry production in the Pacific northwest. Pacific Northwest Ext. PNW 598.

Qin, R., S. Gao, and H. Ajwa. 2013. Emissions and distribution of fumigants as affected by soil moisture in three different textured soils. Chemosphere 90 866-872.

Rudolph, R.E., I.A. Zasada, and L.W DeVetter. 2017. Annual and perennial alleyway cover crops vary in their effects on Pratylenchus penetrans in Pacific northwest red raspberry (Rubusidaeus). J. Nematol. 49:446-456.

Thies, J.A., A.D. Petersen, and D.K Barnes. 1995. Host suitability of forage grasses and legumes for root-lesion nematode Pratylenchus penetrans. Crop Sci. 35:1647-1651.

Van Vleet, S., P. Carter, and R. Higginbotham. 2016. 2015-2016 Winter wheat breeder variety portfolio. Washington State Univ. Ext. TB15E.
Vrain, T., R. DeYoung, J. Hall, and S. Freyman. 1996. Cover crops resistant to root-lesion nematodes in raspberry. HortScience 31:1195-1198.

Walters, T.W., M. Bolda, and I.A. Zasada. 2017. Alternatives to current fumigation practices in western states raspberry. Plant Health Prog. 18:104-111.

Zasada, I.A., J.E. Weiland, Z. Han, T.W. Walters, and P. Moore. 2015. Impact of Pratylenchus penetrans on establishment of red raspberry. Plant Dis. 99:939-946.

Zasada, I.A. and T.W. Walters. 2016. Effect of application timing of oxamyl in nonbearing raspberry for Pratylenchus penetrans management. J. Nematol. 48:177-182. 